\title{
The Impact of World Ranking Systems on Graduate Schools of Business: Promoting the Manipulation of Image over the Management of Substance
}

\author{
Kent V. Rondeau ${ }^{1, *}$ \\ ${ }^{1}$ Faculty of Extension, University of Alberta, Edmonton, Alberta, Canada \\ *Correspondence: Faculty of Extension, University of Alberta, Edmonton, Alberta, Canada. E-mail: kvr@ualberta.ca
}

Received: April 25, 2017

Accepted: May 11, 2017 Online Published: June 14, 2017

doi:10.5430/wje.v7n3p62

URL: https://doi.org/10.5430/wje.v7n3p62

"Rather than genuinely fostering relevant knowledge, the emphasis on ranking seems to be driven by a desire to identify winners and losers in a game of academic prestige." (Adler \& Harzing, 2009, p. 74)

"Many of the rankings-related criteria generate activities that insidiously move us away from a focus on substance and toward a focus on image, because the rules of the game we are playing demand it." (Gioia \& Corley, 2002, p. 115)

"Unless they wake up to the dangers of dysfunctional rankings competition, US business schools are destined to lose their dominant global position and become a classic case study of how myopic decision-making begets institutional mediocrity." (DeAngelo, DeAngelo \& Zimmerman, 2005, p. 1)

\begin{abstract}
This essay explores and examines how rankings and league tables have played (and continue to play) a major and consequential role in how contemporary business schools manage their affairs. It introduces and advances the proposition that rankings promote the short-term manipulation of public reputation (image) projected by business schools at the expense of the long-term investments in quality improvement. When schools shift scarce resources to actions aimed at enhancing their public image in the short-term, the consequences for the quality of the professional education is significantly compromised in the long-term to the detriment of the constituencies that they serve. While this paper focuses mainly on business schools in the United States and Canada, where this author has experienced these consequences first-hand, the effects are similar if perhaps less dramatic, for those professional business programs located in higher education institutions operating in the United Kingdom and Europe. While ranking systems are not going away anytime soon, some potential ways are identified for business schools to escape the deleterious and perverse effects of being captive players in the deadly rankings game.
\end{abstract}

Keywords: academic rankings; business schools; reputation management

\section{Introduction}

Institutions of higher education operate in a global market and performance rankings are very much part of the environment (Hazelkorn, 2011; Mmantsetsa, Wells \& Florea, 2013). Rankings of graduate professional programmes in business in the United Kingdom, the United States, Canada and elsewhere appear to be influential in the decisions of interested parties, including applicants, alumni, employers, as well as program and university administrators (Bickerstaffe \& Ridgers, 2007; Wilkins \& Huisman, 2012). Rankings have a significant impact on a business school's ability to attract top scholars, the most able students, and the funding needed to do cutting-edge research (Hazelkorn, 2008). Schools use rankings and league tables to support claims to excellence and 'world class' status (Marginson \& Wende, 2007). Rankings are touted to encourage greater transparency and to strengthen accountability in higher education (Marginson, 2009). The demand for rankings and for league tables flows from the growing demand for accessible, comprehensive, reliable, and valid information on the quality provided by institutions of higher education, including graduate professional schools of business. Demand for this information is fueled by students who use it to choose where to study. Donors use rankings to make their endowment decisions. The private 
business sector uses them to identify the sources of human talent, while governments use rankings to gauge the global standing of their institutions and their offerings, and as a measure of their national competitiveness. Graduate professional schools such business, law, and medicine use rankings to benchmark their institutions and programs against others deemed 'best in class.' Rankings and league tables inform the strategic policy dialogue that drives improvement; ostensibly by acting as an engine for the promotion of excellence in higher education (Marginson \& Wende, 2007). Research has demonstrated how an improvement in a school's ranking can lead to dramatic increases in applications in following years (Peters, 2007). Conversely, termination rates increase for business school deans after a ratings decline (Fee, Hadlock \& Pierce, 2005). School rankings have been shown to influence the decision making process of MBA applicants more than any other media source (Tyson, 2001). Elbeck (2009) contends that there is an unequivocal relationship between school rankings and student success after graduation. Students from the 'top' schools are able to secure the highest paid jobs.

Ranking institutions of higher education remains a highly contentious and controversial idea, in part because deriving a meaningful assessment for the complex social products that are generated through higher education is highly problematic (Hazelkorn, 2008). Most ranking systems use narrow performance indicators that serve as proxy measures for various elements believed to be associated with quality in education. In summarizing the most frequently used indicators of ranking systems, Usher and Medow (2009) identify eight broad categories of assessment that may be used to guage higher education quality: beginning characteristics, learning inputs - faculty, learning inputs - resources, learning environment, learning outcomes, final outcomes, research, and reputation. In criticizing ranking systems, Sowter (2013, pp. 62) contends that every ranking system has to make one or both of two serious compromises - to sacrifice the inclusion of certain subject institutions due to lack of data for intended measures, and/or to sacrifice the inclusion of intended measures due to a lack of data for certain subject institutions. Regardless of the components of the ranking system that is used, there has been considerable criticism of the methodology employed, the choice of indicators and the weightings, the quality of the data, the biases associated with how the data is collected, and its reliability as a national and international comparator of performance. Indeed, rankings have been criticized as overly simplistic, reflecting expedient, 'close-at-hand' measures that are loose proxies for otherwise highly complex, undefined and contentious phenomena. The tendency to focus on securing expedient proxies (because they are easier to obtain), rather than on more relevant ones (because they are not easy to obtain) is euphemistically stated as "valuing what you count, rather than counting what you value." While national and regional rankings are often able to capture comparable data across a wide range of dimensions, global rankings are more narrowly proscribed. In summarizing the problematic nature of rankings and league tables, Hazelkorn (2013, p. 84) contends that "rankings measure what is easy and predictable, and concentrate on past performance, which benefits older higher education institutions at the expense of new institutions. Quantification is used as a proxy for quality. Given all these shortcomings, it should not be surprising that rankings do not unreservedly measure the quality of education."

Not everyone is alarmed at the methodological problems that confound and undermine the validity of rankings. Surprisingly, some of the strongest and most steadfast support comes from those institutions of higher education that are being ranked. Indeed, academic leaders in highly ranked business schools are more likely to believe in the validity of the rankings than leaders in schools with a lower ranking (Martins, 1998). Highly ranked institutions are powerless to resist the temptation to cite their rarified standing to their relevant stakeholders. Of the 100 business schools listed in the Financial Times global ranking of MBAs in 2006, 96 schools referred to their position on their websites, in press releases, or in the promotional literature they produced (Bradshaw, 2007, p. 54).

Given their sharp biases and extreme limitations, rankings are not going away anytime soon (Bienkowski, Brada \& Stanley, 2012). Nevertheless, their impact on the field of higher education is not inconsequential and needs to be understood (Hazelkorn, 2011). Indeed, rankings and league tables have a profound steering effect on the strategic and operational deliberations of those persons entrusted with leading these institutions. While many educational leaders lament the fact that rankings are a poor indicator of educational quality, as a consequence of being ranked, higher education institutions 'legitimize' the rankings process by taking significant tangible and highly visible actions whose primary aim is to yield higher rankings. Rankings have had, and continue to have, a transformational impact on graduate professional programs in business management (Gioia \& Corley, 2002; Stolz, Hendel \& Horn, 2010). Yet, rankings and league tables have the perverse effect of forcing business schools to alter (and even abandon) their usual efforts at making measured, slow, meaningful, substantive, and tangible improvements to their professional programs - enhancements that might have strengthened them in the long run to an infatuation with their standing in league tables. As a consequence of their involvement in rankings, business schools are more likely to focus their actions on the manipulation of a false image that has been 'fabricated' through their [forced] participation 
in the 'rankings game' (Corley \& Gioia, 2000). DeAngelo and colleagues (2005) argue that rankings have had a seriously adverse impact on business schools in America (and elsewhere). When searching for 'quick fixes' to improve their ranking positions, business schools have (among other things) dumbed-down their MBA programmes to make them easier; starved their undergraduate and doctoral programmes of resources in favour of the MBA program; encouraged prestige-inducing, theoretical research exclusively aimed at publication in elite, 'A-level' journals that little direct influence on managerial practice (Thomas \& Wilson, 2011). In summarizing the crisis, Policano (2001, p. 40) contends that "chasing rankings continues to divert significant resources that could otherwise be allocated to hiring additional faculty and staff, improving classroom technology, keeping curriculum innovative, and providing opportunities for students."

\section{Ranking Business Schools}

Global rankings of higher education institutions have become a burgeoning international phenomenon since 2003 when the Shanghai Jiao Tong Academic Ranking of World Universities (ARWU) was developed to highlight the position of Chinese universities with respect to others in the world (Liu, 2013). In the past ten years, more than 30 ranking systems have emerged, most constructed and promulgated, not by the universities and colleges that are being evaluated, but by global media organizations interested in securing greater sales for their publications (Hazelkorn, 2011). While college and university guides were originally produced to assist students and their parents make informed choices about where to get a high quality undergraduate education, the audience today is much broader, and the stakes are much higher. As the number of rankings increase, the audience has expanded to include international postgraduate students and faculty, other higher educational institutions, governments and policy makers, employers, sponsors, foundations, private investors and industrial partners. Public opinion is strongly influenced by rankings which in turn can positively or perversely affect the support for higher education, for a particular post-secondary institution, and for its various offerings and programs. Rankings have the potential to inform resource allocation and impact institution accreditation, determine and set quality standards, drive modernization and change within higher education institutions, and even influence economic and national policy. Higher ranked post-secondary institutions are able to charge higher tuition, attract top scholars and students, and secure more external funding. These accomplishments enable business schools to secure additional resources so as to deliver the highest standards of learning and by consequence, produce highly employable graduates. All of these things contribute to highly ranked schools maintaining their favourable positions in the rankings in the long term. Non-ranked schools are at a significant disadvantage with respect to their ability to compete with ranked schools because they have little visibility among influential stakeholders from which to influence their reputation. Over time, rankings reinforce and extend existing patterns of perceived image and reputation. Corley and Gioia (2000, p. 329) suggest that rankings produce a 'snowball effect'--one that "promotes a 'rich-get-richer and poor-get-poorer' cycle and creates a 'catch 22' trap from which it is difficult to extricate oneself, win or lose."

Hazelkorn (2011) contends that the burgeoning popularity of rankings and league tables is largely related to their simplicity and ease-of-use. Similar to the ranking of hotels, hospitals, movies, and restaurants, the ranking of higher education institutions appear to provide a user-friendly guide to quality. Although some ranking systems concentrate on the whole institution, there is an increasing focus on sub-institutional rankings by field (e.g. natural sciences, mathematics, engineering, social sciences, graduate studies), or by profession (e.g. business, law, medicine). Some rating systems for institutions of higher education have an international focus, while others are regional or national. Popular global ranking systems include: the Academic Ranking of World Universities (ARWU), the UK-based Times Higher Education Thompson Reuters World University Ranking (THE-TR; updated in 2010), QS World University Rankings (QS; since 2004) and the Performance Ranking of Scientific Papers for Research Universities (HEEACT; since 2007) (Sowter, 2013). Recently there have been efforts to combine and amalgamate separate ranking systems into an overall rankings score (Soh, 2015). It is believed that such an approach might help compensate against the shortfalls of one approach with the strength of another. Many institution-based ranking systems place a heavier weight on research productivity than on teaching effectiveness, a curious anomaly given the importance that students place on good teaching (Hazelkorn, 2011). This can be partially explained by the fact that research activity lends itself more easily to quantitative assessment. It may also be that the research function of higher educations institutions are more prized because they serve as 'reputation-enhancers' and as 'revenue-generators' through their potential to generate lucrative patents and innovations.

With the rise in interest in professional programs in business administration that occurred in the 1980s and 1990s, efforts were been made early on to undertaken to evaluate (and compare) the quality of different Master of Business Administration (MBA) programs (Wedlin, 2006). Since their arrival in 1988, Business Week (BW) magazine ranking 
of US full-time MBA programs has had a significant influence on business school education (Morgeson and Nahrgang, 2008). The first ranking of the top-20 business schools in the United States has now been expanded to the top 85 schools and remains arguably the most influential ranking system for American business schools. It should be noted that despite the fact that rankings are often advertised by their sponsors as 'business school rankings', the most prominent of them are essentially MBA program rankings. Given that impact of rankings on institutional reward structure, business schools now attend to their MBA programs as their highest priority, so much so that these are now considered their "flagship" program, even when research or service animate its faculty and administration.

Ranking MBA programs is not a new phenomenon. In 1990, US News and World Report launched its own ranking of American business schools, focusing more on ratings criteria that are deemed important for students in selecting appropriate places for study. In response to a criticism that business school rankings were too US-biased, the UK-based Financial Times (FT) published its first rankings of global, full-time MBA programs in 1999 (Bradshaw, 2007). To differentiate their rankings from those of competitors, the FT awarded 20 percent for international student diversity and 25 percent for research performance, in addition to 40 percent based on the salary progression of graduates, while 15 percent was awarded for student selectivity (Peters, 2007). In the past few years, many new rankings of business schools have emerged (ie. Wall Street Journal, Forbes, The Economist, Asia Week), while business school rankings have broadened to include rankings for part-time MBA programs, executive MBA programs, distance MBA programs, undergraduate business degree programs, and doctoral programs. While the number of ranking systems has proliferated, there remains a high degree of unanimity across the promulgated rankings with respect to the composition of the top-ranked MBA programs, where there is very little change in positioning year-on-year. Indeed, US-based MBA programs, located in older, wealthier and more prestigious institutions of higher learning, dominate the upper echelon of the top ranked programs in global rankings. For instance, the FT 2014 ratings of global MBA programs shows that American business schools occupy twelve of the top-20 spots where elite schools at Harvard, Stanford, Pennsylvania (Wharton), Yale, Columbia and Dartmouth (Tuck) can be found. Two schools from the United Kingdom (London Business School and the Judge Business School at Cambridge University) are also included in the FT top-20 global MBA programs.

\section{Benefits of Ranking Business Schools}

Although the criticism of rankings comes from many quarters, most pundits recognize and acknowledge that there is some level of 'felt truth' with respect to the value of rankings (Wilkins \& Huisman, 2012). As Gioia and Corley (2002, pp. 110) contend: "the rankings are not absurd; if they were absurd, most schools simply would not treat them seriously...Furthermore they are useful to prospective students and recruiters who previously had to cope with a great deal of managed translucency on the part of schools. Now perspective students and interested recruiters at least have a way of broadly assessing schools on some criteria, with some user-friendly statistics and measures."

At the institutional level, rankings can help focus the minds of educational leaders and faculty on the core business of teaching, research and knowledge transfer, particularly if senior management identifies a clear set of goals in relation to the ranking criteria. Ranking criteria can assist an organization to focus on crucial areas of practice in line with their strategic aspirations.

Rankings and league tables reflect the growing trend in western society to make higher education institutions and their offerings more comparable, transparent, and accountable in an increasingly 'performance-based,' market culture (Marginson, 2009; Webster \& Hammond, 2014). As higher and professional education is increasingly globally accessible to more and more people, rankings are having a democratizing influence - giving higher education a 'mass appeal' and making it everyone's business (Scott, 1995). The prime rationale for the promulgation of rankings is to promote excellence through competition. Global competition in higher education is driving change in national systems (Martins, 2005). Rankings are playing a key role in the quest to create global qualifications and standards in business education (Stanley, 2012). When business school rankings were first introduced, few academic leaders took much notice (Morgeson, \& Nahrgang, 2008). At the time, the culture of innovation that predominated on the campuses of most higher education institutions could be characterized as overly conservative, dogmatic and rigid. It was only after the business community took notice, that rankings provided an important 'wake-up call' to business schools that it could no longer be 'business-as-usual.' As a consequence of introducing rankings, business schools now scramble to make changes much faster with respect to perceived shifts in their environment. Rankings have had the positive effect of markedly increasing the speed of decision making in most business schools (Peters, 2007). Business schools need to be seen a fully responsive to market pressures and ranking systems force them to be that way. 
In the past decade, higher education has been under increasing scrutiny to provide evidence of quality. Increasingly, the emphasis has been on direct accountability to the public, with diminishing investment in relying exclusively on an academically-driven, peer-based system (Eaton, 2013). Societies are increasingly reluctant to rely merely on the organizations and professionals in the field to make judgments about education quality. This new found emphasis on accountability is driven by several factors, all of which reinforce a pragmatic, utilitarian approach to professional education. Rankings have taken their place in this new drive for accountability, along with other 'transparency instruments' that include student prior learning assessments, institutional and programme accreditation, balanced scorecards, and continuous quality improvement initiatives such as Six Sigma and Lean Management (Rice \& Taylor, 2003). There is little debate that the transparency provided by rankings has made business schools more accountable to their stakeholders. Rankings have helped to focus business schools on making changes to their curricula that at least have the potential to make them more responsive to the needs of their key constituent-corporations and business enterprises. Indeed, rankings have played a major role in strengthening and deepening the relationship between business schools and the business community. They have also been instrumental in shifting this power relationship - but with the corporate sector now distinctly having the upper hand. The ascendancy in consumerism in education and the seminal role of global markets for educational products has been facilitated by the proliferation of rankings (Bienkowski, Brada \& Stanley, 2012). Rankings and league tables permit students to make comparative choices across a large number of schools located in diverse geographies. They have also made it easier for higher education institutions to woo the coveted (and highly profitable) international student who now has the ability to assess a business school program without leaving home.

A more general benefit of the rankings is that it has compelled business schools to be more strategic in deciding which domains to enter and how they want to prioritize their program emphases to effectively compete. In the past few years, many business schools have begun to accelerate their reputation-enhancement activity by branding their educational product (Naidoo, Gosling, Boldin, O'Brien, \& Hawkins, 2014). This has created what Barnett and Hansen (1996) have labeled a self-reinforcing 'red queen effect' wherein when one organization attempts to improve its competitive standing through learning, it then provokes enough learning in its competitors to improve their standing too. Rankings have provided a timely catalyst for business schools to formally engage in comprehensive benchmarking exercises against other institutions (Downing, 2013). Its application has transformed institutional comparison processes into a strategic tool, helping business schools and higher education institutions to systematically compare their practices and performance against peer institutions and programs. The use of collaborative benchmarking, encouraged by the various rankings criteria, provides a starting point for evidence-based improvements, and a more thorough understanding of a business school's role against the wider backdrop of similar programs elsewhere in the world. Within institutions of higher education, rankings have encouraged some schools to both collaborate and compete with each other to each achieve a level of excellence and to reach their strategic goals. Nevertheless, it is not yet clear that enough schools are using rankings in this way.

\section{Playing the Rankings Game}

Universities are in the 'reputation enhancement' game. Reputation matters and rankings are both an indicator of reputation and a consequence of that reputation. Although reputation has long been of concern for business schools, academic reputation has always been composed of a set of specific qualities (parameters) that differentiated one school from another (Nguyen \& LeBlanc, 2001). Since their inception, rankings have come to dominate the 'sense-making' and 'action-taking' efforts by business schools and shifted their focus to become active practitioners of the important enterprise of reputation management (Doorley \& Garcia, 2011). Increasingly, MBA program rankings are increasingly viewed as a measure of competitiveness within the business education industry. If business schools want to effectively manage their reputation, they must deal with rankings because rankings play a pivotal role in establishing and extending reputation.

As a consequence of being ranked, business schools are forced to continue to participate in the rankings game. According to Corley and Gioia (2000), the 'rules of the game' are implicit in that no formal statement of them exists, yet their acceptance is essential to remaining a viable participant in 'the game.' Consistent with institutional theory, organizations that do not follow the rules of the game face a loss of organizational legitimacy (Wedlin, 2006). The overseers of the game are the book and magazine publishers who set the rules, which have over time, become institutionalized and accepted. Publishers are also able to change the way that the game is played, and have indeed changed the performance indicators from time to time with little pre-warning, causing institutions to scramble to keep up. Corley and Gioia (2000) contend that the rankings game has four implicit rules. The first and most prominent rule is that "you must play the game" (if you want to be ranked). If a school aspires to be a ranked 
program or a top program, it is essential to participate. Corley and Gioia (2002, p. 323) quote one business school dean as stating: "The reality is that, independent of whether you believe rankings accurately reflect quality, the perception of the outside world is [that] it does, and consequently resources flow to schools who are highly ranked."

The first rule of the rankings game is made more significant when combined with the second rule: "Once you start playing the game, you cannot quit." Corley and Gioia (2002) contend that this is made real in two fundamental ways. First, if a school decides to boycott the surveys sent by the magazines, they are automatically removed from the process and cannot be ranked. This process disqualifies the school from the game without providing it with a chance to explain its reasoning for choosing to not respond. However, for top ranked schools, this rule is somewhat flexible. In 2004, Harvard and Wharton (Pennsylvania) both declined to participate in the Business Week survey, however BW was able to get the information they needed from other sources (reported in DeAngelo, DeAngelo, \& Zimmerman, 2005). This demonstrates the potential for resistance to have a measured impact, (but only if that resistance comes from top ranked schools). Second, current students, administrators, alumni, and some faculty see the school's ranking as proving particular benefits to them. If a school decides not to play the game any longer, each of these powerful constituencies could potentially experience a loss of prestige and power. Together, these factors keep business schools that are being ranked in the game and make leaving the rankings game a difficult proposition to navigate.

The third rule of the rankings game is that "the criteria for the rankings can change without notice." Responding authentically to rankings is impossible because each publisher has a different set of criteria for its rankings. Every year also sees the emergence of new rankings that need to be absorbed. Business school leaders are increasingly being asked to respond to a target that is both moving as well as a target that is constantly morphing. One dean expressed his frustration in this way: "I've been in the rankings business seven years now...because it is a moving target and because everybody else is moving... you have no insight on their data, you don't know what to expect" (quoted in Corley \& Gioia, 2000, p. 324). The rapidly changing landscape with respect to the ranking criteria means that schools are never ever able to absorb a clear message from changes in their ranking position. Beyond informing business schools that they are moving up or down in the rankings, there is no real information conveyed in a rankings number. As a consequence, strategic changes informed as a response to rankings are too often incoherent, piecemeal, and disjointed.

The final rule identified by Corley and Gioia (2000) is that "you can't really win this game (but you still have to look like you are trying)." If winning means being a top ranked school, then only a very small elite group of schools consistently occupies the top position. Indeed, a comparison of the top five ranked MBA schools from FT shows no change between 2012 and 2014 with the same five schools being represented, with almost no change in their positional ranking year-on-year. This long-term consistency of always being at the top reinforces their reputation of being a 'winner' with key stakeholders. Lower rated schools whose rating scores are much more volatile (year-on-year) are unable to transmit to receptive publics any clear and unambiguous message concerning their educational quality. For top ranked schools, ratings allow them to maintain and enhance their favorable reputations, while lower ranked schools scramble to try to establish one, and unranked schools have almost no chance of ever creating one.

\section{The Unintended Consequences of Chasing Rankings}

Hazelkorn (2011, p. 59) contends that rankings have the unique ability "to stir emotional reactions, mostly of the black and white variety with little room for grey. People are either implacably opposed [to them] or favor the concept." Much of the criticism of rankings comes from the quality of the data that is used in the rankings process. Business school rankings draw their information from three main sources: independent third party sources including government databases, higher education institution sources provided by way of response to a survey questionnaire, and from survey data of students, peers, employers or other stakeholders (Usher \& Medow, 2009). Yet, regardless of the source of data, rankings criteria often have only a tangential relationship with what they purport to measure, that is, educational quality (Hazelkorn, 2008).

The measures used to assess the quality of professional business education are highly problematic. Almost all of the criteria used by the various ranking systems fall victim to the criticism that they remain poor proxies for the quality of education they purport to measure. For instance, student entry GMAT (Graduate Management Admission Test) scores are used as a means of assessing the contribution of incoming students to educational quality. Yet, as Hazelkorn (2011) contends, most top ranked business schools recruit great students and then graduate great students, but is this due to the 'quality' of the institution or the 'quality' of the students? Employability and starting salaries of 
graduates is another factor that is used to assess the quality of business schools. However, the overall employability of graduates and their starting salaries is most closely linked to general economic forces and local labor market conditions. It is not inconsequential that the top ranked American business schools are located in the US northeast and in California (near Silicon Valley) where starting salaries for educated business professionals are high. Reputation is assessed by asking peers, alumni and employers the level of esteem they hold toward certain schools. Yet, the overall validity of this type of assessment is highly suspect because assessments are subject to halo effects, to self-serving biases, and to gaming. Assessing the reputation of institutions and programs is also perversely confounded by an echo chamber effect where early sentiment is relentlessly reinforced and extended by the media responsible for producing the rankings (Goldie, Linick, Jabbar, \& Lubienski, 2014). Finally, learning outputs are usually assessed through graduation or program completion rates. However, using 'program completion rates' as a relevant criterion, greatly undermines the agenda aimed at improving access to higher education for economically disadvantaged persons and for visible minorities who may be less likely to complete. As Gioia and Corley (2002, p. 113) lament, "the end result is that a high social value for diversity and for leveling the playing field for minorities is sacrificed to the hegemony of the rankings."

While reporting on educational quality using dubious proxies remains controversial, one of the biggest problems associated with rankings is what they purport to say about the change in business school positioning from one year to the next (Dichev, 1999). It can be easily demonstrated statistically that rankings of top schools are considerably more 'stable' than those of lower ranked schools (Devinney, Dowling \& Perm-Ajchariyawong, 2008). Statistically speaking, "top ranked schools reside in the thinly populated right tail of the school quality distribution, and therefore real differences in their quality are much more substantial and enduring than those for lower-ranked schools residing in the more densely populated regions of this distribution" (Dichev, 2008, p. 219). Among lower ranked business schools, most of the positional change observed from one year to the next can be shown to consist with 'natural' (normal) statistical variation (so called 'system noise'), rather than broadly reflecting any concrete change in the quality of different MBA programs in the time period (Dichev, 2001; 2008). Given the reality of this statistical effect, its implications are quite profound. When business schools take actions with respect to a rise (or fall) in their rankings, they are reacting more to a statistical anomaly that may be more ephemeral than real (Morgeson \& Nahrgang, 2008). Given that most lower ranked schools will often move up (or down) the rankings by as much as ten to 15 positions in any given year, it seems incredulous to believe that strategic program changes that are implemented by these schools in any one year could have such a dramatic impact (on rankings) the next. Among the top ranked schools, positional changes are not subject to as large an amount of statistical variation ('noise') that characterizes the lower ranked schools. Their positions remain more fixed, in part held there by certain 'advantages' not shared by lower ranked schools. These include their sterling reputations established over many years, their dense social networks with important stakeholders, as well as their access to a deep, rich and extensive resource base that these networks provide. Thus, top ranked schools are more likely to remain 'top ranked', while lower ranked schools are highly unlikely ('statistically speaking') to ever become one! The hill to climb for a school to meaningfully rise in the rankings (in a short period of time) is just too steep!

A real problem that is associated with rankings is that small, insignificant differences between business schools are treated as meaningful. This is most true for those programs that are highly ranked, but are not yet considered elite. It is unlikely that there is little to separate a program that is ranked $\# 11^{\text {th }}$ (say) from one ranked $\# 17^{\text {th }}$, yet the top-ranked school gets disproportionate attention and changes in rank are treated as meaningful by all. Publishers of rankings are always eager to exploit any change in the positioning of top ranked schools in their magazines, proclaiming-'We have a new number one!' while perpetuating the illusion that small changes in rankings are real and thus newsworthy. Indeed, changes in rankings are only good for the business of generating higher magazine sales. Gioia and Corley (2002, p. 114) contend that "the magazines are motivated to generate artificial variation - typically by changing their criteria over very short time horizons and without warning. That means B-schools are perpetually playing a catch-up game."

While changes in the quality of professional education can only be realized in the long-run, rankings force business schools to respond to transient changes in ranking, in the short-term. This is exacerbated by brief tenures that are held by most business school deans where the time horizon for achieving substantive change is much longer. Under intense and unrelenting pressure coming from students, alumni, donors, the business sector, university administration, and governments, business school leaders are increasingly having to focus their efforts on producing short-term, superficial changes, aimed ostensibly at influencing the rankings, rather than on making substantive (long-term) changes where sustainable improvements in educational quality are the objective. Increasingly, rankings are a significant factor in the creation of a business school environment that is in almost constant upheaval and whose 
turmoil impedes student learning and the pursuit of faculty knowledge creation (DeAngelo, DeAngelo \& Zimmerman, 2005).

Rankings have also had very real consequences on the curricular content of professional MBA programs (Wilkins \& Huisman, 2012). The narrow focus of business schools on their MBA programs leads schools to allocate their best instructors and a disproportionate share of their financial resources to that program at the expense of undergraduate and doctoral programs. A typical consequence (and one that is observed in my own school) is that the 'best' instructors are often transferred from undergraduate teaching and reassigned to the MBA program. This has the potential to short-change undergraduate education as well as choke-off the production of future researchers who will do the ground-breaking studies needed to improve management theory and practice in the future (DeAngelo, DeAngelo \& Zimmerman, 2005). In an effort to respond to rankings that favour programs that are able to convince their stakeholders that they are 'cool,' 'innovative' and 'leading-edge,' business schools are increasingly making curricular changes that advance topical management practices that are highly 'fashionable, sexy and faddish' (Abrahamson, 1996), while the teaching of established (and worthy) practices and concepts are increasingly discontinued if they do not produce sufficient 'cachet.' Rankings thus have the potential to affect curricular coherence in the long-term because rankings impart forces on the business school curriculum that are increasingly incoherent, irrational, and disjointed. In summarizing the kinds of changes found in the new MBA curriculum that is emerging as a consequence of rankings, DeAngelo and colleagues (2005, p. 18) contend that there is "an emphasis on vocational training, dumbing down strategies in the classroom such as replacing more difficult material with media anecdotes, handing out slogan-like overheads with facile 'takeaways,' excessive [use of] outside speakers, fewer classroom hours due to field trips and other extra-curricular add-ons, [and] classes on 'trendy' topics with little real academic content."

Yet, the biggest impact on rankings on the affairs of business schools, and the higher education institutions in which they are housed, is their ability to shift resources towards those enterprises that rankings suggest are important (Gioia \& Corley, 2002). Rankings induce institutions to introduce structural changes whose only purpose is to create and advance a positive reputation with key stakeholders. As a response to their ranking, business schools are expending considerable resources on 'image management enterprises' whose primary function is to influence reputations that drive improvements in the rankings. Rather than making substantive, purposive, long-term investments aimed at improving teaching quality through the redevelopment of curricula, or making investments in classroom facilities or educational infrastructure, business schools are increasingly responding in the short-term by shifting their (limited) resources to public and media relations, image consultants, and alumni affairs. Rankings are also instrumental at shifting resources aimed at making business schools look more and more distinct from their competitors. Increasingly, business schools are engaging in brand and reputation management efforts where the aim is to create a distinct image that can stand out against a perception (by key publics) that all MBA programs are very much generic (Argenti, 2000; Gopalan, Stitts, \& Herring, 2006). As a way of differentiating their programs even further from their competitors, business schools are spending more resources on supplementary activities such as the funding field trips and foreign excursions that, while highly popular with students, expend resources that are really meant to exploit the creation of 'manufactured difference.'

\section{Conclusion: Getting off the Rankings Game Treadmill}

One of the enduring features that all business schools share is that they do not produce tangible products that can be readily defined and easily communicated. This reality elevates the seminal role of image and its effective management in all its interactions with key stakeholders. Rankings reinforce the importance of reputation, but they markedly reduce the ability of schools to manage their images proactively, ostensibly because the images that business schools project are not primarily of their own making. While institutional and program rankings appear to be an enduring feature of higher education and are unlikely to fade away any time soon, business schools must learn new approaches to playing the game that will not sacrifice their future development. Unless schools learn to change how they play this game, "management education, improperly managed, risks transforming itself into something of an illusory industry if the single ranking number becomes a substitute for more comprehensive assessments of business school quality" (Gioia \& Corley, 2002, p. 117).

Although changing the rankings game remains intractable, business schools need to understand the very serious implications of continuing to play the game in the ways that it is currently being played. Business schools no longer have the luxury of lamenting the means by which rankings identify 'winners and losers' while acting in ways that reinforce notions that the rankings are valid predictors of educational quality. Indeed, business schools are 
duplicitous when they make substantive changes in their curricula as a response to a ranking and then turn around and say that the ranking process (that predicated the changes in the first place) are fundamentally invalid. Yet, given the very real consequences of not responding to rankings, what are business schools to do in a world of rankings?

First, schools need to move away from the short-term myopia that characterizes the kinds of changes promulgated by the rankings to embrace more of a long-term, strategic perspective. Adler and Harzing (2009) recommend that business schools need to consciously and purposefully 'decouple' themselves from the deleterious impact that rankings have on their strategic management. Because most changes in the rankings position reflects 'statistical noise' rather than true changes in educational quality, schools need to stop 'validating' the rankings process by making short-term quick fixes in response to changes in their ranking. Second, business schools need also to uncouple rankings from the resource steering effects that rankings produce. While doing this may make for some rather creative approaches, unless this is done, the future long-term viability of high quality business education will be seriously compromised. Third, schools need to communicate better with their key stakeholders their very serious concerns about the methodological problems inherent in various ranking approaches. This kind of information is unlikely to ever come from the magazines that perform the rankings, and unless institutions of higher education pursue an agenda aimed at educating the end users of rankings about their limitations, business schools will be held to account for their ranking, regardless of whether they are valid or not. Fourth, business schools and institutions of higher education need to become much more involved in the development and promulgation of the quality criteria that are used to evaluate and rank them. While recognizing the need to have an 'arms-length relationship' with the rankings process in order to maintain the confidence in the integrity of the rankings process, business schools need to work more closely with those ranking organisations so that their concerns can be better understood and acted upon. Fifth, business schools need to reemphasize their commitment to undergraduate teaching. Many business schools in the quest to secure higher rankings through the pursuit of reputation-enhancing actions that favors research over teaching, have abandoned their responsibilities in this regard. Sixth, Lynch (2015) suggests that business schools need to 'unmask the tyranny of numbers' to which they slavishly adhere. This requires that business schools to resist the lure of managerialism that has given rise to rankings, and to build a counter-hegemonic discourse that reflect broader societal values that "are grounded in the principles of democracy and equal participation that are at the heart of the public education tradition" (p. 202).

Finally, business schools can use the resource gains that are produced by successfully playing the rankings game to pursue a 'substance-image-substance strategy' (Gioia \& Corley, 2002). Because the outcome of the rankings game produces winner and losers, those who succeed at making reputational enhancements (through improved rankings) can re-invest the resource gains that are accrued into making substantial improvements to business education quality that serve the broader public good. In this way, rankings can produce the kinds of positive and meaningful changes that are needed to carry business schools into tomorrow and beyond!

\section{References}

Abrahamson, E. (1996). Management fashion. Academy of Management Review, 21(1), 254-285. https://doi.org/10.5465/AMR.1996.9602161572

Adler, N.J., \& Harzing, A.W. (2009). When knowledge wins: transcending the sense and nonsense of academic rankings. Academy of Management Learning and Education, 8(1), 72-95. https://doi.org/10.5465/AMLE.2009.37012181

Argenti, P. (2000). Branding B-schools: reputation management for MBA programs. Corporate Reputation Review, 3(2), 171-178. https://doi.org/10.1057/palgrave.crr.1540111

Barnett, W.P., \& Hansen, M.T. (1996). The red queen in organizational evolution. Strategic Management Journal, 17, 139-157. https://doi.org/10.1002/smj.4250171010

Bickerstaffe, G., \& Ridgers, B. (2007). Ranking of business schools. Journal of Management Development, 26(1), 61-66. https://doi.org/10.1108/02621710710720103

Bienkowski, W., Brada, J.C., \& Stanley, G. (Eds.). (2012). The university in the age of globalization. Rankings, resources and reforms. Basingstoke, UK: Palgrave MacMillan. https://doi.org/10.1057/9781137023032

Bradshaw, D. (2007). Business school rankings: the love-hate relationship. Journal of Management Development, 26(1), 54-60. https://doi.org/10.1108/02621710710720095

Corley, K., \& Gioia, D. (2000). The ranking game; managing business school reputation. Corporate Strategic 
Review, 3(4), 319-333. https://doi.org/10.1057/palgrave.crr.1540123

DeAngelo, H., DeAngelo, L., \& Zimmerman, J.L. (2005). What's really wrong with US business schools? Unpublished manuscript, Marshall School of Business, University of Southern California. Retrieved from: https:// fisher.osu.edu/ young.53/DeAngelo-DeAngelo-Zimmerman.pdf.

Devinney, T., Dowling, G.R., \& Perm-Ajchariyawong, N. (2008). The Financial Times business school rankings: what quality is this signal of quality? European Management Review, 5(4), 195-208. https://doi.org/10.1057/emr.2008.14

Dichev, I.D. (1999). How good are business school rankings? Journal of Business, 72(2), 201-213. http://www.jstor.org/stable/10.1086/209610

Dichev, I.D. (2001). News or noise? Estimating the noise in the US News university rankings. Research in Higher Education, 42(3), 237-266. https://doi.org/10.1023/A:1018810005576

Dichev, I.D. (2008). Comment on 'Financial Times business school ranking: what quality is this signal of quality?' European Management Review, 5(4), 219-224. https://doi.org/ 10.1057/emr.2008.23

Doorley, J., \& Garcia, H.F. (2011). Reputation management. The key to successful public relations and corporate communication (2nd Edition). New York: Routledge.

Downing, K. (2013). What's the use of rankings? In M. Mmantsetsa. P.J. Wells, \& S. Florea (Eds.), Rankings and accountability in higher education. Uses and misues. Paris: UNESCO, pp. 197-208. https://doi.org/10.2478/msd-2014-0006

Eaton, J. (2013). Rankings, new accountability tools, and quality assurance. In M. Mmantsetsa. P.J. Wells, \& S. Florea (Eds.), Rankings and accountability in higher education. Uses and misuses. Paris: UNESCO, pp. 129-137. https://doi.org/10.2478/msd-2014-0006

Elbeck, M. (2009). Advancing the relationship between business school ranking and student learning. Journal of Higher Education Policy and Management, 31(1), 81-88. http://dx.doi.org/10.1080/13600800802559294

Fee, C.E., Hadlock, C.J., \& Pierce, J.R. (2005). Business school rankings and business school Deans: a study of nonprofit governance. $\quad$ Financial $\quad$ Management, $\quad 34(1), \quad$ 143-166. http://dx.doi.org/10.1111/j.1755-053X.2005.tb00095.x

Gioia, D.A., \& Corley, K.G. (2002). Being good versus looking good: business school rankings and Circean transformation from substance to image. Academy of Management Learning and Education, 1(1), 107-120. https://doi.org/10.5465/AMLE.2002.7373729

Goldie, D., Linick, M., Jabbar, H., \& Lubienski, C. (2014). Using bibliometric and social media analyses to explore the 'echo chamber' hypothesis. Educational Policy, 28(2), 281-305. https://doi.org/10.1177/0895904813515330

Gopalan, S., Stitts, K., \& Herring, R. III. (2006). An exploratory investigation of the branding strategies of the top 50 global MBA programs. Journal of International Business Research, 5(2), 49-61.

Hazelkorn, E. (2008). Learning to live with league tables and ranking: the experience of institutional leaders. Higher Education Policy, 21(2), 193-215. https://doi.org/10.1057/hep.2008.1

Hazelkorn, E. (2011). Rankings and the reshaping of higher education. The battle for world-class excellence. Basingstoke, UK: Palgrave MacMillan.

Hazelkorn, E. (2013). World-class universities or world class systems? Rankings and higher education policy choices. In M. Mmantsetsa. P.J. Wells, \& S. Florea (Eds.), Rankings and accountability in higher education. Uses and misuses. Paris: UNESCO, pp. 71-94. https://doi.org/10.2478/msd-2014-0006

Liu, N.C. (2013). The academic ranking of world universities and its future direction. In M. Mmantsetsa. P.J. Wells, \& S. Florea (Eds.), Rankings and accountability in higher education. Uses and misuses. Paris: UNESCO, pp. 24-39. https://doi.org/10.2478/msd-2014-0006

Lynch, K. (2015). Control by numbers: new managerialism and ranking in higher education. Critical Studies in Education, 56(2), 190-207. http://dx.doi.org/10.1080/17508487.2014.949811

Marginson, S. (2009). University rankings, government and social order: managing the field of higher education according to the logic of the performative present-as-future. In M. Simons, M. Olssen, \& M. Peters (Eds.), Re-reading education policies: a handbook for studying the policy agenda for the $21^{\text {st }}$ century, Rotterdam: Sense Publishers, pp. 584-604. 
Marginson, S., \& van der Wende, M. (2007). To rank or to be ranked: the impact of global rankings in higher education. Journal of Studies in International Education, 11(3/4), 306-329.

Martins, L.L. (1998). The very invisible had of reputational rankings in US business schools. Corporate Reputation Review, 1(3), 293-298. https://doi.org/10.1057/palgrave.crr.1540051

Martins, L.L. (2005). A model of the effects of reputational rankings on organizational change. Organization Science, 16(6), 701-720. https://dx.doi.org/10.1287/orsc.1050.0144

Mmantsetsa, M., Wells, P.J., \& Florea, S. (Eds.). (2013). Rankings and accountability in higher education. Uses and misuses. Paris, United Nations Educational, Scientific and Cultural Organization (UNESCO). https://doi.org/10.2478/msd-2014-0006

Morgeson, F.P., \& Nahrgang, J.D. (2008). Same as it ever was: recognizing stability in the BusinessWeek rankings. Academy of Management Learning and Education, 7(1), 26-41. https://doi.org/10.5465/AMLE.2008.31413860

Naidoo, R., Gosling, J., Boldin, R., O'Brien, A., \& Hawkins, B. (2014). Leadership and branding in business schools: a Bourdieusian analysis. Higher Education Research and Development, 33(1), 144-156. http://dx.doi.org/10.1080/07294360.2013.864612

Nguyen, N., \& LeBlanc, G. (2001). Image and reputation of higher education institutions in students' retention decisions. International Journal of Education Management, 15(6), 303-311. https://doi.org/10.1108/eum0000000005909

Peters, K. (2007). Business school rankings: content and context. Journal of Management Development, 26(1), 49-53. http://dx.doi.org/10.1108/02621710710720086

Policano, A.J. (2001). Ten easy steps to a top-25 MBA program. Selections, 1(2), 39-40.

Rice, G.K., \& Taylor, G.C. (2003, September 30). Continuous improvement strategies in higher education: a progress report. Boulder, CO: EduCause Center for Applied Research.

Scott, P. (1995). The meanings of mass higher education. Buckingham, UK: Open University Press.

Scott, P. (2013). Ranking higher education institutions: a critical perspective. In M. Mmantsetsa. P.J. Wells, \& S. Florea (Eds.), Rankings and accountability in higher education. Uses and misuses. Paris: UNESCO, pp. 113-137. https://doi.org/10.2478/msd-2014-0006

Soh, K. (2015). What the Overall doesn't tell about world university rankings: examples from ARWU, QSWUR, and THEWUR in 2013. Journal of Higher Education Policy and Management, 37(3), 295-307. http://dx.doi.org/10.1080/1360080X.2015.1035523

Sowter, B. (2013). Issues of transparency and applicability in global university rankings. In M. Mmantsetsa. P.J. Wells, \& S. Florea (Eds.), Rankings and accountability in higher education. Uses and misuses. Paris: UNESCO, pp. 55-68. https://doi.org/10.2478/msd-2014-0006

Stanley, G. (2012). Challenges in the quest to create global qualifications and standards are diving change in education systems. In W. Bienkowski, J.C. Brada \& G. Stanley(eds.), The university in the age of globalization. Rankings, resources and reform. Basingstoke, UK: Palgrave MacMillan, pp. 3-25. https://doi.org/10.1057/9781137023032_1

Stolz, I., Hendel, D.D., \& Horn, A.S. (2010). Ranking of rankings: benchmarking twenty-five higher education ranking systems in Europe. Higher Education, 60(5), 507-528. https://doi.org/10.1007/s10734-010-9312-z

Thomas, H., \& Wilson, A.D. (2011). 'Physics envy', cognitive legitimacy or practical relevance: dilemmas in the evolution of management research in the UK. British Journal of Management, 22(3), 443-456. https://doi:10.1111/j.1467-8551.2011.00766.x

Tyson, G. (2001). A look behind the numbers. Selections, Fall, 8-15.

Usher, A., \& Medow, J. (2009). A global survey of university rankings and league tables. In B.N. Kehm \& B. Stensaker (Eds.), University rankings, diversity, and the new landscape of higher education. Rotterdam: Sense Publications.

Webster, R.L., \& Hammond, K.L. (2014). Market orientation effects on business school performance: views from two management levels. Academy of Educational Leadership Journal, 18(4), 231-244.

Wedlin, L. (2006). Ranking business schools: forming fields, identities and boundaries in international management 
education. Cheltenham, UK: Edward Elgar. https://doi.org/10.4337/9781847200273

Wilkins, S., \& Huisman, J. (2012). UK business school rankings over the last 30 years (1980-2010): trends and explanations. Higher Education, 63(3), 367-382. https://doi:10.1007/s10734-011-9446-7 